\title{
Effectiveness of Double System Education Programs in Education Curriculum Performance Vocational High School
}

\author{
Lubban Anwari Alhamidi ${ }^{1}$, Prasetio Ariwibowo ${ }^{2}$, Tjipto Djuhartono ${ }^{3}$ \\ \{lubbanalhamidi@yahoo.com ${ }^{1}$, prasetio.ariwibowo@yahoo.com², tjiptodjuhartono@gmail.com ${ }^{3}$ \} \\ Indraprasta PGRI University, Jakarta, Indonesia ${ }^{1,2,3}$
}

\begin{abstract}
This research is descriptive in nature with the method of describing students performance appraisal in a number of Vocational High Schools in Jakarta, Bogor and Bekasi that focuses on the assessment of the Dual System Education program. In this study the data analysis technique used is the Stake Model Evaluation Research design, in the form of stages, consisting of input, processes, and outputs, as a process of recording objective conditions, Analysis as a standardized actualization with intensity or objective conditions, and decisions with follow-up recommendations. The results of the evaluation of antecedent components include several aspects: evaluation in the recruitment process of prospective students, teacher administrative requirements, the School curriculum, the PSG program is conducted twice on odd and even semester entertainment, facilities and infrastructure, PSG program financing. It concludes by arguing that doubleshift schools appear to offer an adequate education and therefore appear to be a viable solution (at least in the short to medium term) for countries seeking to expand their secondary education systems within resource constraints.
\end{abstract}

Keywords: Vocational High School, Dual Systems Education, Performance, Curriculum, Students.

\section{Introduction}

In the era of Industry 4.0, the competition of every company engaged in any sector in any sector of the industry was increasingly sharp. This intense competition requires every company to be able to meet every need and desire of consumers and business partners (markets). With these conditions, every company is required to have Human Resources who have and can provide the best quality of service so that the company can survive in business competition with its competitors. There is a human development approach and the UNDP 2030 Agenda has three general analytical relations [1].

The human development program and the UNDP 2030 agenda are anchored in the universalism of the human development approach by emphasizing increasing freedom for every human being and the 2030 Agenda by concentrating on not leaving anyone behind. The human development program and the UNDP Agenda have the same focus areas to eradicate extreme poverty, end hunger, reduce inequality, ensure gender equality, and so on. The human development program and UNDP Agenda have sustainability as a core principle. Human resources have a very vital role for a company. One of the important activities of human resource management is the assessment of recruitment results obtained from various educational institutions as labor providers, both from secondary education 
institutions (high schools and vocational high schools) to the higher education circles (tertiary institutions). School is a social interaction system of an organization as a whole consisting of personal interactions related together in an organic relationship [2]. Whereas based on Law No. 20 of 2003 concerning SISDIKNAS Article 1 paragraph 1, Education is a conscious and planned effort to create an atmosphere of learning and learning process so that students actively develop their potential to have religious spiritual strength, self-control, personality, intelligence, noble character, and the skills needed by himself, society, nation and country. According to Law No. 20 of 2003 concerning SISDIKNAS Article 1 paragraph 7, the education pathway is a vehicle through which students learn to develop their own potential in an educational process that is in line with educational goals. Law No. 20 of 2003 concerning SISDIKNAS Article 17 explains that secondary education is a continuation of basic education.

Secondary education consists of general secondary education and vocational secondary education. Secondary education in the form of High School (SMA), Madrasah Aliyah (MA), Vocational Middle School (SMK), and Vocational Aliyah Madrasah (MAK), or other forms of equivalent. SMK has been seen as a school/secondary education institution that can produce graduates who can work directly with the required job qualifications and can compete in the labor market. Specifically for SMKs, the Government of the Republic of Indonesia has implemented a Dual System Education System (PSG) in its learning activities (curriculum), which is expected that every student who graduates from a Vocational School has the qualified to be absorbed by various companies that need quality workforce theoretically and practically in the short term, medium term, to long term. Dual system education is expected to be an alternative pattern of learning in vocational schools stipulated in the Decree of the Minister of Education and Culture of Indonesia Number 323/U/1997 article 1 paragraph 1, namely: and synchronize educational programs in vocational high schools with the mastery of skills gained through working directly in real work at a partner institution, directed to achieve a certain level of professional expertise [3].

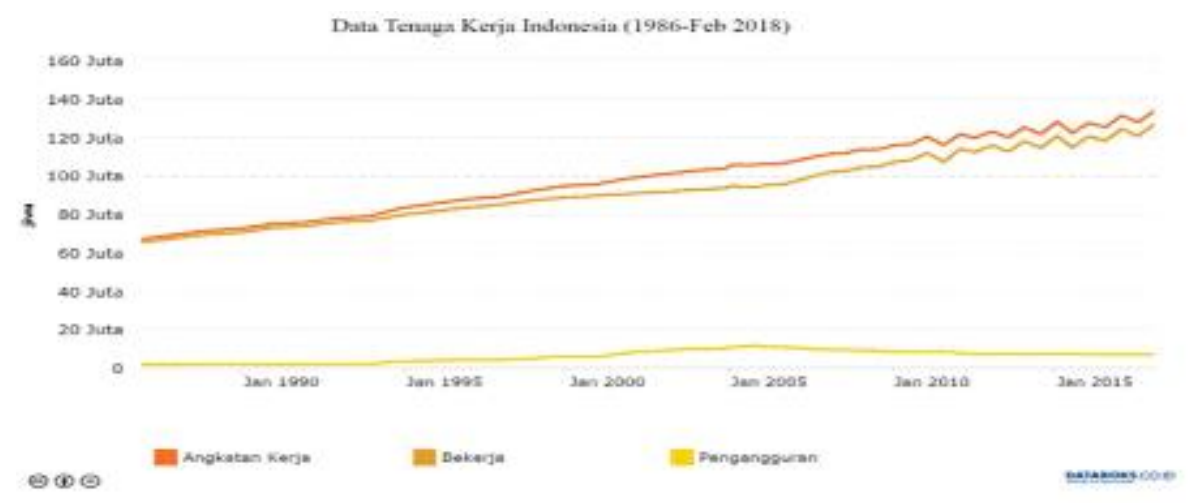

Fig 1. Indonesian Labor Data Period 1986 - February 2018

The number of the workforce shows a growth trend as Indonesia's population grows. Likewise, the number of labor force employed recorded an increase from year to year. The workforce in 1986 only reached 67 million, then in 2002 it reached 100 million. Data from the Central Statistics Agency (BPS) recorded that the Indonesian labor force in February 2018 increased $1.82 \%$ to 133.94 million people from the position in February 2017. While the workforce data that worked grew $2.03 \%$ to 127.07 million. As a result, the 
number of unemployed people fell $1.93 \%$ to 6.87 million. The working age population in February this year reached 193.55 million people while those who were not the labor force 59.61 million people. The Open Unemployment Rate (TPT) in February this year fell by 20 basis points (bps) to 5.13\% from February year then and also dropped 37 bps from the position in August 2017. TPT This is the lowest since 1998. In fact, there is still a significant gap between the number of SMK graduates and the amount that is able to be absorbed by industry and the world of work. From the TPT, as the Head of BPS stated that the most unemployed were graduates of Vocational High Schools (SMK) which were 11.41 percent [4].

The majority of SMKs in Indonesia do not provide good feedback on industry needs today in the form of personal communication, adaptability, managerial ability, ability to solve problems both working individually or in groups, or other forms of feedback to students regarding the quality of skills that have been achieved. These data indicate that almost all SMKs in Indonesia are still ineffective in producing alumni who have high quality skills or minimum skills expected by companies in the world of work. The various unclear procedures and standardization of PSG applied by each Vocational School in producing the skills of graduates of the Vocational School alumni have an impact on students' discomfort and unfairness, such as related to the low hardskill and soft skills obtained by students. This has become one of the factors of the highest high unemployment rate, which is 11.41 percent of vocational high school (SMK) graduates [4]. Some even argue, in Indonesia, many people are highly educated, but have low abilities. Departing from these conditions, there needs to be improvement in terms of preparing and implementing a curriculum that is truly based on the needs or demands of the industry, namely by implementing the PSG (Dual System Education) program more seriously, the PSG Program must be able to accommodate all needs, both the needs of the company and the needs of employees. One method that can be used to measure the level of success of the PSG program is applied to the level of quality of skills (hardskill and soft skills) of students, the Behaviorally Anchor Rating Scale Method. Behaviorally Anchor Rating Scale Method is a valuation method that aims at a combination of critical incidents and ratings (quantified ratings) using a scale that specifically describes good and bad performance [5]. This method can be the right solution. This is because this method is very accurate in assessing the work behavior of each employee [5]. In addition, the Management by Objectives method can also be used. This method can be an answer to the industry's needs for the quality level of effective student and school skills. This is because this method contains a set of standards that are the target of the achievement of every student and school that can be measured periodically. This standard can be a reference for Vocational High Schools to determine the level of productivity of each student. Through this level of student productivity companies (industry) and schools can assess the extent of the performance of each prospective employee and alumni of their students effectively. It is expected that by using these two methods, all Vocational High Schools in Indonesia will be able to create comfort and justice and be able to motivate students to improve the quality of their skills.

\section{Research Method}

This research is descriptive in nature by describing a symptom, event and event that is happening at this time. This method seeks to illustrate the problem regarding the performance / skills assessment of students in a number of vocational high schools 
(Vocational High Schools) in Bogor and Bekasi districts which are the focus of research in which the assessment of the PSG program on the quality of skills of students which has so far been performed is ineffective or inappropriate with the needs and desires of the industry / company. The population includes all stake holders in several SMKs, namely students, teachers, employees, school management and related parties of the program. The selection of informants (samples) purposively according to the criteria was obtained by 12 key informants, namely a School Principal, a Vice Principal in the curriculum and energy sector, a Program Person in charge, a New Student Admission Committee, three Productive Teachers involved in the program, three Students, and two Instructors in the pair industry. Referring to the characteristics of this study, the data collection techniques used in this study include:

1. Observation is basically recording activities on something by utilizing sensory functions (visual).

2. Interview is essentially a process of communication between two or more people who have certain goals.

3. The questionnaire is a data collection technique that is done by giving a set of questions or written questions to respondents to answer [6].

4. Documentation is a data collection technique sourced from documents (written/textual material, films or other recordings) that are not specifically prepared because of a request from a researcher [7]. The documentation method is a method of collecting data sourced from written goods [8], documentation studies are data collection techniques that are not directly addressed to research subjects. The validity of the findings or data in research is absolutely necessary to meet the scientific principles of research. To guarantee the validity of the data obtained is done through checking or checking the data, then the credibility of the data is done by several techniques [7], namely:

a. Triangulation of sources.

b. Triangulation of methods / techniques.

c. Triangulation of peers.

d. Theory triangulation.

In this study to obtain valid data done by triangulation of sources and triangulation of methods / techniques. In this study the data analysis technique used is the Stake Model Evaluation Research design, in the form of:

1. Stages, consisting of inputs (antecedents), processes (transactions), and results (outputs).

2. Observation, as a process of recording objective conditions.

3. Analysis, as a standard actualization with objective intensity or conditions.

4. Decisions with follow-up recommendations.

From the design of the evaluation model above the researcher takes the example of a dual system education evaluation adopted from the results of previous research or relevant research conducted by A.Muliati AM, who builds a terms of reference involving three components of the stakeholder model evaluation, the three components are as follows: Evaluation at the input stage contains the analysis of issues related to what conditions existed before the program was implemented and factors that would influence, identify and assess system capabilities, alternatives, strategies, programs, design procedures for implementation strategies [9]. Evaluation of input program is oriented towards a program that can be achieved and what is desired, sub-components that are the focus in evaluating the input of multiple system education programs. Evaluation at the process stage is an evaluation that is designed and applied in a practical process or guiding in the 
implementation of activities, including identifying procedures for implementing both the management of events and activities, to reveal the implementation of multiple system education. Evaluation of results is an evaluation conducted in measuring the success of achieving the goals set. Outcome evaluation activities are efforts to measure and interpret the results achieved from a program.

\section{Results And Analysis}

\subsection{Results}

Antecedent component. The results of the evaluation of the antecedent component include several aspects: The first aspect, there are 3 (three) sub-aspects that are evaluated in the recruitment process of prospective students, namely not color blind, physically and mentally healthy, and interview tests, all of which are included in the high category. No color blindness is the main requirement for students who will enter SMK Negeri 51 Jakarta, SMK Yadika 9 Bintara Bekasi \& SMK DarmawanSentul - Bogor, because if students are color blind the students will not be able to distinguish the factors of production. On recruitment, when registering students are required to bring a health certificate from the health center. After the prospective students were accepted, the school conducted a test that was not color blind, and was physically and mentally healthy again, even though at the beginning the prospective student brought a certificate from the puskesmas. The sub-aspect of the interview test does not determine whether the student is accepted or not but only to find out whether the prospective student who enrolled is indeed the student's own wish or the wish of the parents. In addition, interviews were conducted to find out whether parents are ready with school funding for their children.According to Law Number 20 of 2003 that vocational education is education that prepares students to work in certain fields. Related to the process of student recruitment in the antecedents component, the requirements to be able to attend education in this school are non-negotiable requirements because they relate to the field of work after the students have completed their education. If the student is color blind, how can work in the field of Tourism \& Hospitality, Office Administration \& Management, and the field of Arts \& Creative Industries that require accuracy in their work and are based on differences in the factors of production used.

The second aspect, teacher administrative requirements. All productive teachers have a Bachelor's degree in Tourism \& Hospitality, Office Administration \& Management, and Creative Arts \& Industry and professional certificates in Tourism \& Hospitality, Office Administration \& Management, and Creative Arts \& Industry. They also teach according to a diploma. Their teaching experience is $>5$ years, to be exact since school was founded. Productive teachers with training experience consist of $5 \rightarrow 10$ people from $10->20$ teachers at SMK Negeri 51 Jakarta, SMK Yadika 9 Bintara Bekasi \& SMK Darmawan Sentul Bogor. Training/education and training that are followed by productive teachers are education and training to carry out cross- supervision when the productive component UN takes place. Because education and training are routine once a year, the number of teachers who have experience in training will increase every year. Increasing the competence of educators becomes a necessity, as Hamalik points out, vocational education is a form of talent development, basic education skills, and habits that lead to the world of work which is seen as training in skills. Based on this, of course it takes teachers who have competent competence [10]. 
The third aspect, curriculum. The school implements the 2006 curriculum (KTSP). The competency standards applied in this school are relevant to SKKNI. Schools have not $100 \%$ synchronized curriculum with industry, so the curriculum structure still uses a standard curriculum structure.

The fourth aspect, academic calendar. Observation results show: PSG program carried out twice, namely: on odd semester holidays and even semester holidays.

The fifth aspect, facilities and infrastructure. $75 \%$ of school facilities and infrastructure are appropriate. So it is included in the high category.

The sixth aspect, PSG program financing shows a low category. This will certainly have an impact on the implementation of other activities, so that in its implementation schools need operational funding assistance from the school foundation, the central government and the Regional Education Office.

Transactions component. The results of the observations of the transaction component include KBM consisting of 4 aspects and 16 sub-aspects, and training activities in the industry consisting of 3 aspects and 14 sub-aspects. Of the 16 sub-aspects of the KBM, 15 subaspects fall into the high category and 1 sub-aspect in the low category. Of the 15 high-quality sub-aspects, namely: the making of lesson plans, preparation of standard competency assessments/tests, teacher mastery in presentation of material based on competencies, competency-based learning, use of methods/media that vary according to competence, use of learning modules according to competence, use of materials/standardized practice tools, giving competency tests at the end of PBM, providing remedial material for students who are not yet competent, giving attention to all students, giving feedback every KBM, intensity of feedback, administration of collaborative texts with industry, placement of practice work for class XI students, and presentation of student work practices. The high category in the KBM sub-aspects was achieved because of the strong commitment of each subject teacher, especially productive subjects and because of the leadership and support of the School Principal who was very cooperative, transparent, full of responsibility, and able to create a family climate.

In addition, the availability of adequate facilities and student motivation is quite high. These factors are very supportive of the achievement of KBM in this school with a high category. One sub-aspect is categorized as low, related to KBM, namely the preparation of learning modules based on competence. Productive teachers who teach basically have special notes related to the learning material that will be delivered to students. These notes if compiled based on the systematic writing of a book, it can be said as a learning module. Learning modules that are prepared by the subject teacher who teaches in a class can have a positive impact on learners in the form of learning motivation, because the modules they use are prepared by their teachers not by others.

Furthermore, aspects of training activities in the industry include 3 aspects with 14 sub-aspects. Of the 14 sub-aspects all included in the high category, namely: place of work practice in the field of Tourism \& Hospitality, Office Administration \& Management, and the field of Arts \& Creative Industries, industry experience accepting student work practices for at least 1 year, minimum instructor education background D3, instructor work experience of at least 1 year, experience of guiding instructors of at least 1 year, there are even some teachers and instructors with Masters degrees. Mastery of student work practices including high categories, strategies / methods of guidance that vary, jobs are trained in the industry in accordance with the competency of the student's expertise program, practice time is at least 2 months, use of equipment and practice materials according to standards, complete journal entries by students $\geq 90 \%$, assessment of the results of work 
practices $\geq 80 \%$ with the correct assessment procedures, granting certificates of work practice in industry $90 \%$ of the number of students, and monitoring from teachers at least once a month.

Giving a certificate of work practice in the industry is given to all students who take the PSG program. The certificate is given by the school based on the place of work practice of each student, that is the Community Health Center where students carry out work practices. Certificate of work practices at partner institutions other than government companies, private to state and private higher education in the form of certificates have not been obtained by all students.

Outcomes component. The results of the observations of the components of outcomes include 4 aspects, namely the results of the UN, Productive Component UN results, Absorption of graduates in the world of work, and waiting time for graduates to be absorbed in the world of work, and 6 sub-aspects, namely: a minimum of $50 \%$ of students receive a Mathematics UN score $\geq 55.0$; a minimum of $50 \%$ of students receive an English Language UN score $\geq 55.0$; a minimum of $50 \%$ of students receive an Indonesian Language UN score $\geq$ 55.0; at least $90 \%$ of graduates have a UN Productive Component score of $\geq 70$; and certified, graduates are absorbed in the world of work $\geq 80 \%$, and a minimum of $50 \%$ graduates have a waiting time of $<2$ months. Of the 3 aspects evaluated from the first aspect, all results of the UN (National Examination) which reach objective standards. Nevertheless, the basic abilities of students related to English subjects must continue to be improved, this is because in practice the mastery of English students is still weak and only theoretically mastered. The second aspect is the results of the productive component UN have a high category because $100 \%$ of graduates have a value $\geq 70.0$; and all graduates are certified.

The third aspect is the absorption of graduates in the world of work that have not yet reached an objective standard, namely the absorption of graduates in the world of work $\geq 80 \%$. The absorption of graduates in the world of work which is only $68 \%-78 \%$ should be a serious concern of the school management, because absorption is the final goal to be achieved. The success or failure of the school program can be seen from how much graduates are absorbed in the world of work. Tracing of graduates should be done systematically, so schools can find out the conditions of graduates.

The fourth aspect is that the waiting time for graduates to be absorbed in the workforce has met the objective standard, which is less than one month graduates are directly absorbed in the world of work. The waiting time of only one month is a school achievement, because it proves the confidence of the industrial world in the graduates that are quite high. The objective standard for waiting time is bulan 2 months, because after graduation is declared graduated in June, 2 months later is the ideal waiting time, because if 2 months have not been absorbed in the industry, graduates can make other efforts such as registering at tertiary institutions to continue lecture while waiting for a job call in the industrial world. Based on the findings it can be seen the relationship between the components being evaluated, namely:

1. In the recruitment process, it does not require the UN results as a condition for the admission of new students and the absence of an academic potential test causes the school not to know the academic potential of the student properly, so in compiling programs related to improving the quality of education in this school is not based on authentic data. This results in national examination results in mathematics and English that reach the criteria, namely $65-86 \%$ of students receive a Mathematics and English score $\geq 55.0$ but in practice there are still some students who are weak in both speaking, listening and writting (TOEFL, IELTS, etc). This is illustrated 
by Muliati's research, which conducted a document search of the average academic test scores from three subjects, namely Indonesian, English and Mathematics, and tracing the Vocational High School Values [9]. With the data they have, schools can arrange programs to improve the quality of education and prepare their students for the coming national exams. Based on these conditions, Muliati found that $98 \%$ of students passed the UN, and $93 \%$ of students passed the Productive Components UN.

2. Schools focus on the transactions component. This can be seen in the results of the evaluation where there are only 1 sub-aspects that do not meet objective standards. This condition led to the productive component UN results of all students Graduating with a value of dengan 70.0 and being certified.

3. In the antecedents evaluation, recruitment of prospective students needs to be improved: the academic potential test needs to be conducted, although it is not used as a benchmark for acceptance or failure of prospective students, the test results can be used as material for mapping students' basic abilities and as a reference data for the UN results improvement program.

4. Curriculum, it is necessary to pay attention to synchronizing the school curriculum with the needs in the Tourism \& Hospitality industry, Office Administration \& Management, and the Arts \& Creative Industry sector. Funding is an equally important resource for improving the quality of education. Schools need to empower all existing potential in order to obtain sources of funding through production units or sponsors.

5. Assessment of the implementation of student work practices in industry is very important. Assessment to measure students' abilities and become input for the school about the relevance of the material in schools with work standards in the industry.

6. National Mathematics and English National Examination scores that do not meet practical criteria should receive attention from school management, especially the mapping of students' basic abilities through tests of academic potential. The absorption of graduates in the world of work who have not yet reached the criteria can be overcome by holding a job fair for graduates who have just graduated so that graduates can be fully absorbed in the world of work.

\subsection{Analysis}

Of the 3 aspects evaluated from the first aspect, all results of the UN (National Examination) which reach objective standards. The second aspect is the results of the productive component UN have a high category because $100 \%$ of graduates have a value $\geq 70.0$; and all graduates are certified. The third aspect is the absorption of graduates in the world of work that have not yet reached an objective standard, namely the absorption of graduates in the world of work $\geq 80 \%$. The absorption of graduates in the world of work which is only $68 \%-78 \%$ should be a serious concern of school management, because absorption is the final goal to be achieved. The fourth aspect is that the waiting time for graduates to be absorbed in the workforce has met the objective standard, which is less than one month graduates are directly absorbed in the workforce. The waiting time of only one month is a school achievement, because it proves the confidence of the industrial world in the graduates that are quite high. The objective standard for waiting time is bulan 2 months, because after the graduate is declared graduated in June, 2 months later is the ideal waiting time, because if 2 months have not been absorbed in the industry, graduates can 
make other efforts such as registering at tertiary institutions to continue lecture while waiting for a job call in the industrial world.

This is in accordance with the best strategic priorities in order to increase public interest in education in order to achieve educational productivity in the future, namely "Increasing Managerial Input Skills, Growing market/marketing share, Optimizing Capital / facilities and infrastructure. which is owned by an educational institution" [11].

\section{Conclusion}

The conclusions from the evaluation results can be described as follows:

\subsection{Antecedents}

The results of the evaluation of the antecedent component include several aspects: The first aspect, there are 3 (three) sub-aspects that are evaluated in the recruitment process of prospective students, namely not color blind, physically and mentally healthy, and interview tests, all of which are included in the high category. No color blindness is the main requirement for students who will enter SMK Negeri 51 Jakarta, Yadika 9 Bintara Bekasi Vocational School \& DarmawanSentul Vocational School - Bogor, because if students are color blind students will not be able to distinguish the factors of production when working in the industrial world. The second aspect, teacher administrative requirements. All productive teachers have a Bachelor's degree in Tourism \& Hospitality, Office Administration \& Management, and Creative Arts \& Industry and professional certificates in Tourism \& Hospitality, Office Administration \& Management, and Creative Arts \& Industry. They also teach according to a diploma. Their teaching experience is $>5$ years, to be exact since school was founded. Productive teachers with training experience consist of 5 -> 10 people from 10 -> 20 teachers at SMK Negeri 51 Jakarta, SMK Yadika 9 Bintara Bekasi \& SMK DarmawanSentul - Bogor. Training / education and training that are followed by productive teachers are education and training to carry out cross-supervision when the productive component UN takes place. The third aspect, curriculum. The school implements the 2006 curriculum (KTSP). The competency standards applied in this school are relevant to SKKNI. Schools have not $100 \%$ synchronized curriculum with industry, so the curriculum structure still uses a standard curriculum structure. The fourth aspect, academic calendar. Observation results show: the PSG program is carried out twice, namely: on odd semester holidays and even semester holidays. The fifth aspect, facilities and infrastructure. $75 \%$ of school facilities and infrastructure are appropriate. So it is included in the high category. The sixth aspect, PSG program financing shows a low category. This will certainly have an impact on the implementation of other activities, so that in its implementation schools need operational funding assistance from the school foundation, the central government and the Regional Education Office.

\subsection{Transactions}

The results of the observations of the transaction component include KBM consisting of 4 aspects and 16 sub-aspects, and training activities in the industry consisting of 3 aspects and 14 sub-aspects. Of the 16 sub-aspects of the KBM, 15 sub-aspects fall into the high category and 1 sub-aspect in the low category. Of the 15 high-quality sub-aspects, namely: the making of lesson plans, preparation of standard competency assessments / tests, teacher 
mastery in presentation of material based on competencies, competency- based learning, use of methods / media that vary according to competence, use of learning modules according to competence, use of materials / standardized practice tools, giving competency tests at the end of PBM, providing remedial material for students who are not yet competent, giving attention to all students, giving feedback every KBM, intensity of feedback, administration of collaborative texts with industry, placement of practice work for class XI students, and presentation of student work practices. The high category in the KBM sub-aspects was achieved because of the strong commitment of each subject teacher, especially productive subjects and because of the leadership and support of the School Principal who was very cooperative, transparent, full of responsibility, and able to create a family climate.

\subsection{Outcomes}

The results of the observations of the components of outcomes include 4 aspects, namely the results of the UN, Productive Component UN results, Absorption of graduates in the world of work, and waiting time for graduates to be absorbed in the world of work, and 6 sub-aspects, namely: a minimum of $50 \%$ of students receive a Mathematics UN score $\geq 55.0$; a minimum of $50 \%$ of students receive an English Language UN score $\geq 55.0$; a minimum of $50 \%$ of students receive an Indonesian Language UN score $\geq 55.0$; at least $90 \%$ of graduates have a UN Productive Component score of $\geq 70$; and certified, graduates are absorbed in the world of work $\geq 80 \%$, and a minimum of $50 \%$ graduates have a waiting time of $<2$ months.

Acknowledgments. The researcher presents his sincere appreciation goes to Mr. Drs. M. Sjamsuri, MM. as the Head of LPPM Indraprasta PGRI University Jakarta for his supervision, advice, and guidance from the very early stage of this research as well as giving me extraordinary experiences throughout the past few years. The researcher also thanked the LPPM team of Jakarta Indraprasta PGRI University who had financed the research trip to completion. Then to Mr. Rahmat Darsono, M.Pd.as Headmaster of SMK Darmawan Sentul, Suyamti, S.Pd, M.M.as Headmaster of SMK Negeri 51 Jakarta, Mr. Parlagutan Sinaga as Headmaster of SMK Yadika 9 Bintara - Bekasi who has helped him patiently finishing this research by giving suggestion, guidance, and correction until the completion of this research.

The biggest award from the researchers was also addressed to DoniAndraand The 2th ICOPE (International Conference on Progressive Education) 2020 team as editor member for your advice, supervision, and important contributions in improving the results of this research, from this article to the submission that this article can be published in one of Journal of The 2th ICOPE 2020, October 17-18, 2020, Lampung,Indonesia.

\section{References}

[1] Jahan, Selim. 2015. Human Development Report 2015. New York: United Nations Development Program.

[2] Admodiwiro, Soebagio. 2000. Management Education. Jakarta: PT Ardadizya.

[3] Ministry of Education and Culture of the Republic of Indonesia. 1997. Decree of the Minister of Education and Culture of the Republic of Indonesia Number 323 / U / 1997 concerning the Implementation of Dual System of Education. Jakarta: Ministry of Education and Culture. 
[4] Suharyanto. 2019. Introduction to Ethics and Skills Needed in the World of Work. 2018. Jakarta. DOI: https://www.youthmanual.com/post/guide-include-smk/guide-reparing- works-forgraduates-smk/introduction-is-and-and-the- skills- needed-in-the-world-work. Accessed February 21 ,

[5] Dessler. 2013. Human Resources Management Human Resources. Jakarta. Prenhalindo. Volume 2.

[6] Sugiyono. 2010. Educational Research Methods Quantitative, qualitative and R\&D Approaches. Bandung: Alfabeta.

[7] Moleong, Lexy J. 2000. Qualitative Research Methodology. Bandung. PT RemajaRoshdaharya.

[8] Suharsimi and Arikunto. 2002. Research Methodology A Proposal Approach. Jakarta: PT. Rineka Cipta.

[9] Muliati,A. 2008. Evaluation of the Dual System Education Program, An Evaluative Research based on the Stake's Countenance Model Regarding the Dual System Education Program at a Vocational School in South Sulawesi. Dissertation. Jakarta: Jakarta State University.

[10] Hamalik, Oemar. 2004. Manajemen Pengembangan Kurikulum. Jakarta, Bumi Aksara.

[11] Elfian, Ariwibowo, P., Johan, R. S. 2017.The Role of Higher Education in Increasing Public Interest for Educational Productivity. Sosio-ekons Journal. Vol 9, No 3. Page 200-215. 